\title{
Relatywizm wartości i norm współczesnego świata z perspektywy filozofii biblijnej
}

\author{
The Relativism of the Values and Norms \\ of the Modern World from the Perspective \\ of Biblical Philosophy
}

\begin{abstract}
ABSTRAKT
Celem artykułu jest spojrzenie z perspektywy biblijnej na współczesny relatywizm wartości i norm. Za pomoca filozofii biblijnej próbujemy porównać sytuacię ponowoczesnego chrześcijanina oraz wyznawcy starożytnego judaizmu, spotykajq̨cego się z kulturq hellenistycznq. Przedmiotem naszej refleksji sq fragmenty Księgi Koheleta oraz Księgi Mqdrości. Pierwszy punkł zawiera omówienie kultury ponowoczesnej oraz hellenistycznej. W drugim znajduje się zarys historii Izraela w epoce hellenistycznej. Trzeci punkt to egzegeza wybranych fragmentów Księgi Koheleta oraz Księgi Madrości. Zakończenie zawiera próbę aktualizacji postaw autorów biblijnych wobec hellenizmu, w kontekście ponowoczesnego chrześcijaństwa.
\end{abstract}

StOWA KLUCZOWE

filozofia biblijna, Księga Koheleta, Księga Mq̨dró́ci, postmodernizm, teodycea

KEYWORDS

biblical philosophy, Ecclesiastes, Book of Wisdom, post-modernism, theodicy

SPI Vol. 21, 2018/4

ISSN 2450-5358

e-ISSN 2450-5366

DOI: 10.12775/SPI.2018.4.005

Nadesłano: 29.09.2018

Zaakceptowano: 10.12.2018

Artykuły i rozprawy 


\section{ABSTRACT}

The aim of the article is to investigate the contemporary relativism of values and norms from the biblical perspective. By means of biblical philosophy, we try to compare the situation of a post-modern Christian and the followers of ancient Judaism when they met with Hellenistic culture. The subject of our reflection are fragments of Ecclesiastes and the Book of Wisdom. The first chapter contains a discussion of post-modern and Hellenistic culture. The second contains an outline of the history of Israel in the Hellenistic era. The third point is the exegesis of selected passages of Ecclesiastes and the Book of Wisdom. The ending is an attempt to update the attitudes of biblical authors towards Hellenism in the context of postmodern Christianity.

\section{Wprowadzenie}

W jaki sposób można najlepiej scharakteryzować współczesny chaos wartości i norm? Posłużmy się słowami Zygmunta Baumana, który nawiązując do myśli Gillesa Lipovetsky'ego, w takich słowach charakteryzuje ponowoczesność:

[...] weszliśmy wreszcie w epokę l'après-devoir, erę „postdeontyczną”, w której nasze uczynki zostały uwolnione od resztek „nieskończonych obowiązków”, przykazań i „absolutnych zobowiązañ”. W naszych czasach samopoświęcenie nie ma już uzasadnienia; nie wymaga się już od ludzi (a i sami ludzie się do tego nie kwapią), by wytężali się w imię moralnego samodoskonalenia i obrony wartości moralnych; politycy porzucili utopie; wczorajsi ideowcy przeistoczyli się w pragmatyków. Najpowszechniejszym dziś hasłem jest: „precz z przesadą”. Żyjemy w epoce nieskażonego indywidualizmu i pogoni za dobrym życiem, ograniczanych tylko wymogiem wzajemnej tolerancji (gdy łączy się ona z pozbawionym skrupułów i nienękanym wątpliwościami indywidualizmem, może przybrać tylko formę obojętności). Era „postdeontyczna” uznać może tylko moralność szczątkową, minimalistyczną ${ }^{1}$.

W takiej przestrzeni aksjonormatywnej postmodernizmu funkcjonuje również współczesne chrześcijaństwo, które głosi istnienie obiektywnych wartości i norm. Czy przesłanie etyczne chrześcijaństwa musi zadowolić się miejscem jednego z wielu ponowoczesnych dyskursów,

1 Z. Bauman, Etyka ponowoczesna, przeł. J. Bauman, J. Tokarska-Bakir, Warszawa 2012, s. 7. 
rezygnując ze swojego uniwersalistycznego charakteru? Czy zderzenie nowoczesności i ponowoczesności jest faktycznym zmierzchem tradycyjnych wartości, przekazywanych w filozofii i teologii chrześcijańskiej? Problemy tego typu nie są niczym nowym w historii idei. Różnego rodzaju filozofie i religie na przestrzeni wieków stawały wobec problemu zderzenia $z$ nowymi ideami i nowymi paradygmatami kulturowymi, które skutkowały zanikiem jednych oraz nieprzewidzianym rozwojem drugich.

Co może powiedzieć filozofia biblijna współczesnemu chrześcijaninowi, stojącemu wobec problemu chaosu aksjonormatywnego? Jeżeli, zgodnie z głębokim przeświadczeniem dogmatycznym Kościoła, uznajemy Pismo święte za wciąż aktualny i normatywny, natchniony zbiór ksiąg, a nie jedynie historyczny dokument starożytnego Bliskiego Wschodu i basenu Morza Śródziemnego, to jaki może być głos Biblii w interesującym nas temacie? Kontekst historyczny, społeczny, kulturowy i religijny poszczególnych ksiąg Pisma świętego diametralnie różni się od świata ponowoczesnego. Nie możemy szukać w Starym i Nowym Testamencie prostych odpowiedzi na nurtujące współczesnego człowieka pytania. Jednak stosując właściwą hermeneutykę, możemy zaangażować autorytet i głos Biblii do współczesnej dyskusji. Na tym zasadza się założenie projektu filozofii biblijnej.

Ten proces hermeneutyczny powinien rozpocząć się od poszukiwania podobnego lub analogicznego problemu, jak ten doświadczany współcześnie. Następnie, stosując współczesne metody interpretacji biblijnej, należy dokonać analizy kontekstu historycznego i społecznego porównywanego zagadnienia. Szczególnie istotnym elementem tego procesu badawczego jest kolejny etap, czyli egzegeza wybranych tekstów biblijnych, bazująca na takich podejściach i metodach, jak metoda historyczno-krytyczna, podejście retoryczne, narratywne, socjoretoryczne itp. Po zakończeniu interpretacji biblijnego odpowiednika interesującego nas zagadnienia, należy dokonać hermeneutycznego „przekładu” i ,aktualizacji”. Innymi słowy, chodzi o taką hermeneutykę, która dokona „uwspółcześniającej” interpretacji przesłania biblijnego, zachowującego dystans pomiędzy „światem” Biblii oraz współczesnym „światem”2.

2 W ramach procesu „aktualizacji” przesłania biblijnego można wykorzystać m.in. filozofię hermeneutyczną H.-G. Gadamera: tenże, Prawda i metoda. Zarys hermeneutyki filozoficznej, przeł. B. Baran, Warszawa 2007. 
W niniejszym artykule spróbujemy, opierając się na powyższych założeniach hermeneutycznych, stanowiących zarys metodologii filozofii biblijnej, spojrzeć na współczesny problem chaosu aksjonormatywnego w świetle Księgi Koheleta i Księgi Mądrości. W pierwszym punkcie postaramy się znaleźć historyczno-kulturowy ekwiwalentu współczesnego chaosu wartości i norm. Następnie dokonamy zarysu historyczno-socjologicznego tego problemu. W trzecim punkcie dokonamy egzegezy wybranych tekstów z Księgi Koheleta i Księgi Mądrości, dotyczących badanego problemu. Ostatnia część artykułu będzie zawierała próbę hermeneutycznego „zaktualizowania” orędzia biblijnego, w kontekście problemu chaosu aksjonormatywnego.

\section{Chaos aksjonormatywny a pojawienie się hellenizmu na starożytnym Bliskim Wschodzie}

Spróbujmy najpierw dokonać pewnej charakterystyki zjawiska chaosu aksjonormatywnego, czyli dotyczącego wartości oraz norm. Nasze rozważania nie będą jednak prowadzone z jakiejś bliżej nieokreślonej, „obiektywnej” perspektywy, bo takowej faktycznie nie ma. Spojrzymy na problem wspomnianego chaosu wartości i norm, przyjmując punkt widzenia współczesnego chrześcijanina, należącego do zachodniego kręgu kulturowego. Ponowoczesność, w której funkcjonuje, będąc reakcją na postoświeceniowy modernizm, przyniosła ze sobą skrajny indywidualizm oraz relatywizm wartości i norm. O ile różne systemy myśli w Oświeceniu i modernizmie, rywalizując z chrześcijańskim, a ściślej z katolickim światopoglądem rościły sobie pretensję do uniwersalizmu i obiektywizmu, o tyle postmodernizm radykalnie odcina się od takich intencji. Oświeceniowe i postoświeceniowe etyki, chcąc zastąpić moralność chrześcijańską, bazowały na samym rozumie, którego aktywność miała rozwiązać wszelkie moralne dylematy ludzkości. Ponowoczesność z założenia neguje te absolutystyczne i utopijne roszczenia rozumu, proponując współczesnemu człowiekowi różnego rodzaju „dyskursy”, „narracje” moralne, które ten może dowolnie wybierać, modyfikować i nieustannie zmieniać. Innymi słowy, chrześcijanin XXI wieku i jego chrześcijański świat wartości i norm jest tylko jednym $\mathrm{z}$ wielu „dyskursów”, który mimo że deklaruje obiektywność i uniwersalizm, nie 
może jednak pełnić takiej roli. Współczesny chrześcijanin, w myśl ponowoczesności, nie musi również kurczowo trzymać się tego swojego „dyskursu”, może go dowolnie zmieniać, dodając lub odejmując poszczególne elementy. Podmiot moralnych decyzji jest tak płynny, jak płynne są poszczególne „dyskursy” moralne i systemy wartości. Dotychczasowy gmach chrześcijańskiego światopoglądu ulega zatem rozkładowi, ponieważ wydaje się, że jego uniwersalizm i obiektywizm zupełni nie przystają do ponowoczesnego świata. Czy w starożytności możemy zaobserwować jakąś analogię do doświadczenia współczesnego chrześcijanina?

Wydaje się, że takim momentem w dziejach antycznego Izraela był okres hellenistyczny (IV-II w. przed Chr.), kiedy to tradycyjny judaizm, ukształtowany po powrocie z deportacji babilońskiej (VI/V w. przed Chr.), musiał zmierzyć się z pojawieniem się kultury hellenistycznej. Wczesny judaizm, w okresie perskim, charakteryzował się monoteistyczną koncepcją Boga połączoną ze swoistym regionalizmem i partykularyzmem. Jedyny Bóg, stwórca świata i człowieka, noszący imię YHWH, wybrał bowiem jeden naród, mianowicie Izraela, z którym związał się szczególnym związkiem zwanym przymierzem. W myśl tej idei Bóg obiecywał błogosławieństwo, na co lud Boży odpowiadał poprzez posłuszeństwo Torze (Prawu), związane ściśle z zachowaniem religijnej i etnicznej tożsamości. Cała kultura wczesnego judaizmu opierała się na tych założeniach. Wkroczenie na tereny Bliskiego Wschodu, w tym na Ziemię Izraela, kultury greckiej zachwiało światem ideowym wielu wyznawców judaizmu. Hellenizm przyniósł radykalnie nowe koncepcje i doktryny, bardzo często wyraźnie sprzeczne ze światopoglądem opartym na Torze Mojżesza. Hellenistyczny, synkretyczny politeizm niósł ze sobą wartość uniwersalizmu. Bogowie Bliskiego Wschodu otrzymywali imiona bóstw panteonu hellenistycznego. W ten sposób utwierdzało się przekonanie, że tak naprawdę ludzie w różnych miejscach ówczesnego świata czczą tych samych bogów, używając jedynie lokalnych nazw i imion. Hellenizm promował nowy ideał wychowania i edukacji, określany jako paideia. Wiązało się to $\mathrm{z}$ wprowadzaniem różnego rodzaju nowych instytucji publicznych, służących propagowaniu greckiego ducha i światopoglądu. Upowszechniała się literatura grecka i filozofia. Wreszcie językiem komunikacji międzynarodowej, lingua franca, stał się grecki koine. Wiele $\mathrm{z}$ tych nowych idei i instytucji stanowiło wyzwanie i zagrożenie 
dla judaizmu i jego wyznawców. Czy światopogląd judaistyczny z jego systemem wartości i norm mógł nadal funkcjonować w dotychczasowej formie w kontekście hellenistycznego uniwersalizmu? ${ }^{3}$

Widzimy więc, że sytuacja współczesnego chrześcijanina wykazuje wiele analogii z problemami, przed jakim stawał wyznawca tradycyjnego judaizmu w okresie hellenistycznym. W obu przypadkach ich własny „dyskurs”, system wartości i norm, staje wobec konkurencyjnych „dyskursów”, które pozbawiają go prawa i roszczeń do wyłączności i absolutności. Jak zatem literatura biblijna odnosi się do starożytnego chaosu aksjonormatywnego, doświadczanego przez wyznawcę judaizmu $\mathrm{z}$ epoki hellenistycznej? $\mathrm{Na}$ te pytania postaramy się odpowiedzieć, odwołując się do Księgi Koheleta oraz Księgi Mądrości.

\section{Historia Izraela w okresie hellenistycznym}

Aby poprawnie uchwycić przesłanie Księgi Koheleta i Księgi Mądrości, warto dokonać krótkiego, syntetycznego przeglądu dziejów starożytnego Izraela w okresie hellenistycznym, czyli od IV do II w. przed Chr. Jest to okres naznaczony pojawieniem się na terenach Bliskiego Wschodu, w tym w Ziemi Izraela, greckiej kultury hellenistycznej, która na wielu płaszczyznach wpłynęła na historyczny, społeczny i kulturowy krajobraz ludu Bożego ${ }^{4}$.

Po śmierci Aleksandra Wielkiego w Babilonie, w roku 323 przed Chr. imperium przez niego stworzone zostaje podzielone pomiędzy jego wojskowych dowódców, zwanych diadochami. Bliski Wschód podzielono pomiędzy Ptolemeusza i Seleukosa. Ten pierwszy otrzymał we władanie Egipt, natomiast drugiemu przypadły w udziale Mezopotamia i Syria. Ziemia Izraela praktycznie przez cały III wiek

3 Szczegółowa charakterystyka hellenistycznego kontekstu judaizmu: K. Siwek, Honor sprawiedliwego $i$ wstyd bezbożnego w antropologicznokulturowej interpretacji Mdr 1-5, Warszawa-Ząbki 2016, s. 83-184; J. Mélèze-Modrzejewski, Żydzi nad Nilem. Od Ramzesa II do Hadriana, przeł. J. Olkiewicz, Kraków 2000, s. 67-199; M. Hengel, Judaizm and Hellenism, trans. J. Bowden, t. 1, Philadelphia 1974, s. 6-106.

4 Poniższy zarys historyczny opracowano na podstawie: J.C. VanderKam, Wprowadzenie do wczesnego judaizmu, przeł. P. Krupczyński, Warszawa 2006, s. 24-45; J. Warzecha, Historia dawnego Izraela, Warszawa 2005, s. 426-468; P. Johnson, Historia Żydów, przeł. M. Godyń, M. Wójcik, A. Nelicki, Kraków 1993, s. 105-118. 
przed Chr. znajdowała się pod zwierzchnością dynastii Ptolemeuszów. Pojawienie się Greków na terenach Judei nie pozostało bez echa w świecie żydowskim. Hellenizm przynosi ze sobą grecką filozofię, elementy swojego systemu religijnego, idee społeczne, polityczne, architekturę, sztukę itp. Rozpoczyna się proces stopniowego przenikania tych różnych elementów do kultury Izraela, co wiąże się z wieloaspektowym i wieloetapowym przekształcaniem kultury żydowskiej. Oczywiście są środowiska, które chętniej ulegają hellenizacji, jak np. niektóre kręgi kapłańskiej arystokracji. Z kolei inne grupy, o bardziej konserwatywnej postawie, uznają wpływy greckie za niebezpieczne dla tożsamości ludu Bożego. Niemniej w III w. przed Chr. obserwujemy powolne, stopniowe i pokojowe oddziaływanie hellenizmu na Judejczyków. Na całym Bliskim Wschodzie upowszechnia się również dialekt języka greckiego, zwany koine („wspólny”).

Wpływ hellenizmu jest o wiele bardziej widoczny i interesujący w diasporze egipskiej. Diaspora ta kształtowała się stopniowo od momentu schyłku i upadku Królestwa Judei (VII/VI w. przed Chr.). Wielu członków proegipskiego i antybabilońskiego stronnictwa właśnie w kraju faraonów znajdowało schronienie. Archeologom udało się odkryć papirusy pochodzące z Elefantyny, z okresu perskiego (V w. przed Chr.), zapisane w języku aramejskim, które są świadectwem życia tej diaspory. Pojawienie się Ptolemeuszów i kultury greckiej przyczyniło się do silnej hellenizacji wspólnoty żydowskiej w Egipcie. Największa liczba Żydów mieszkała w Aleksandrii. W tym mieście wykształciła się bardzo specyficzna forma judaizmu, otwarta na wartości kultury hellenistycznej, zwłaszcza na wpływy filozofii stoickiej i platońskiej. W III w. przed Chr.w Aleksandrii rozpoczął się proces przekładu Biblii hebrajskiej na język grecki. Mimo że w okresie III i II w. przed Chr. udało się przełożyć większość ksiąg Starego Testamentu, przede wszystkim Torę Mojżesza, proces powstawania Biblii Greckiej, zwanej Septuagintą (=LXX), trwał do I w. po Chr. Nie było to zwykłe tłumaczenie, ale próba wyrażenia biblijnej wiary w kontekście kultury hellenistycznej. Niektóre księgi, takie jak Tora (Rdz, Wj, Kpł, Lb, Pwt), są bardzo bliskie oryginałowi. $\mathrm{Z}$ kolei inne, jak np. Hi, stanowią parafrazą i reinterpretacją tekstu semickiego. Najbardziej znanym przedstawicielem judaizmu aleksandryjskiego był filozof Filon, żyjący na przełomie I w. przed Chr. i I w. po Chr. Jego dzieła, będące w głównej mierze alegorycznymi 
komentarzami do Tory, łączą w sobie stoicko-platońską filozofię $\mathrm{z}$ wiarą biblijną. Są to dzieła pisane przepięknym językiem greckim, wskazujące na doskonałą znajomość kultury hellenistycznej przez Filona.

Na początku II w. przed Chr. Seleucydzi zdobywają kontrolę nad Ziemią Izraela. Panowanie Antiocha IV Epifanesa (175-163 przed Chr.) rozpoczyna szereg wydarzeń, które radykalnie przeobrażą religijno-społeczny krajobraz Judei. W wyniku korupcji władz syryjskich nowym arcykapłanem zostaje Jazon, należący do ugrupowania skrajnych hellenistów. $Z$ urzędu zostaje zdjęty szanowany i wierny judaizmowi Oniasz III, który zostanie niedługo potem zamordowany w Egipcie. Rozpoczyna się polityka bardzo agresywnej implementacji kultury greckiej do życia religijnego i społecznego Judejczyków. Głównym celem reformatorów jest hellenizacja judaizmu, w duchu synkretyzmu. W międzyczasie dochodzi do walki pomiędzy Jazonem a Menelaosem o urząd arcykapłana. Starania te wygrywa drugi z kandydatów. Proces hellenizacji nie ustaje. Sytuacja w polityce wewnętrznej wspólnoty Judejczyków jest napięta. W 169 r. przed Chr. Antioch rabuje skarby świątyni w Jeruzalem, dokonując jej profanacji. Jazon ciągle nie rezygnuje z prób odzyskania władzy. Od roku 168/167 Antioch IV Epifanes rozpoczyna proces brutalnej hellenizacji. Judejczycy są zmuszani do składania ofiar na pogańskich ołtarzach i spożywania wieprzowiny, w ramach ofiarnych uczt. Zakazane zostaje, pod karą śmierci, obrzezanie, będące znakiem przymierza z Bogiem Izraela, niszczone są zwoje Tory. Wielu wiernych judaizmowi ponosi śmierć męczeńską. Wśród nich są m.in. członkowie ruchu chasydów, czyli „pobożnych” (hebr. chasyd oznacza "pobożnego"). Nie prowadzą oni walki ani nie uciekają w szabat, co wykorzystują Syryjczycy, atakując ich właśnie w tym dniu. Świątynia w Jeruzalem zostaje zhellenizowana. Bóg Izraela YHWH ma być czczony jako Zeus Olimpijski. Dla wiernych judaizmowi jest to oczywiście akt profanacji najświętszego miejsca ich religii. W 167 r. przed Chr., w miejscowości Modin, w górach Judei, wybucha bunt. $\mathrm{Na}$ jego czele stają członkowie pokolenia kapłańskiego Matatiasz oraz jego synowie, Jan, Szymon, Juda, Eleazar i Jonatan. Po śmierci ojca w 166 r.przed Chr., dowództwo powstania przejmuje Juda, zwany Machabeuszem. Powstańcy postanawiają, że nie będą w szabat prowadzić ataków, dopuszczają jednak możliwość obrony. Wojna z Seleucydami ma charakter walki partyzanckiej. Machabeusze unikają opuszczania 
gór Judei, na których mają przewagę. Pojedynki na równinie nadmorskiej, przeciwko regularnej armii grecko-syryjskiej, są skazane na porażkę. W roku 164 przed Chr. powstańcom udaje się zdobyć Jeruzalem i dokonać oczyszczenia świątyni z pogańskiego kultu. Na pamiątkę tego wydarzenia ustanowione zostaje święto Chanuka. Dzięki zręcznej polityce prowadzonej z Seleucydami, następcy Judy, Jonatan (160-143 przed Chr.) oraz Szymon (143-134 przed Chr.) powoli zyskują coraz więcej niezależności dla Judei. Jonatan sprawuje władzę nie tylko militarną, ale jednocześnie polityczną i kapłańską. Ten fakt jest przyczyną wielu konfliktów w społeczności wyznawców judaizmu. Nie wszyscy godzą się na tak ścisłe łączenie władzy świeckiej i religijnej w rękach jednej osoby.

Od momentu panowania Jana Hirkana (134-104 przed Chr.) możemy mówić o powstaniu niepodległego państwa Hasmoneuszów. Po kilku wiekach, od czasów upadku Królestwa Judy (VI w. przed Chr.), Żydzi ponownie odzyskują polityczną autonomię. W czasach rządów Aleksandra Janneusza (103-76 przed Chr.) terytorium państwa hasmonejskiego osiąga stan przybliżony do tego z okresu zjednoczonej monarchii. Galilea, która w okresie powygnaniowym zamieszkana była przez ludność pogańską, z nieliczną mniejszością żydowską, za Hasmoneuszów przechodzi proces judaizacji. Jest to jednak judaizm, który w wielu swoich obszarach uległ wpływom hellenizmu o różnym charakterze. Okres panowania dynastii hasmonejskiej charakteryzuje się swoistą syntezą tradycyjnego judaizmu z ówczesną kulturą grecką. Hellenizm, w różnym oczywiście stopniu, stał się punktem odniesienia dla wielu dzieł biblijnych z tego czasu, w tym dla Księgi Koheleta i Księgi Mądrości.

\section{Księga Koheleta a relatywizacja tradycyjnych wartości i norm}

Księga Koheleta (=Koh) jest dziełem anonimowego autora, który podpisuje się imieniem króla Salomona, uchodzącego w starożytnym Izraelu za symbol mądrości i wiedzy. Ten zabieg literacki, zwany pseudoepigrafią, był rozpowszechniony w piśmiennictwie antycznym, a jego celem było podniesienie rangi dzieła oraz nawiązanie do słynnego patrona. $Z$ treści Koh możemy jednak wywnioskować, że jej autor był judejskim mędrcem, przynależącym do wyższych warstw społecznych 
i mieszkającym w Jeruzalem. Wśród egzegetów trwały liczne dyskusje dotyczące czasu powstania księgi. Wydaje się, że opinia utrzymująca, że Koh została napisana w III w. przed Chr. jest najbardziej prawdopodobna. W warstwie językowej hebrajskiego tekstu dostrzegamy liczne arameizmy, ale badacze nie wykluczają również obecności wpływu języka greckiego. Natomiast w treści księgi oraz poglądach Koheleta dostrzegamy liczne, mniej lub bardziej wyraźne, ślady obecności instytucji i myśli greckiej. Chodzi przede wszystkim o tzw. ludową filozofię, która w okresie hellenistycznym docierała do różnych krajów basenu Morza Śródziemnego i Bliskiego Wschodu. Kohelet, który zapoznał się z ludowymi odłamami hellenistycznych filozofii, bliskimi epikureizmowi oraz sceptycyzmowi, nie rezygnując jednak ze swojej hebrajskiej tożsamości, krytycznym okiem spogląda na klasyczne problemy tradycji mądrościowej Izraela. W naszych rozważaniach ograniczymy się jedynie do problemu teodycei, który będzie punktem wyjścia naszych refleksji na temat stosunku judaizmu do kultury hellenistycznej ${ }^{5}$.

Kohelet wyraża wątpliwość w możliwość znalezienia odpowiedzi na pytanie o sens cierpienia. Tradycyjna doktryna bliskowschodnia, podzielana przez Izraelitów, czego wyrazem jest chociażby Prz, utrzymywała, że dobre postępowanie skutkuje błogosławieństwem i pomyślnością bogów/Boga, natomiast zło i nieprawość prowadzi do przekleństwa i nieszczęść. Na gruncie teologii wczesnego judaizmu ta idea przybrała postać przymierza bilateralnego, w ramach którego wierność Torze warunkuje Boże błogosławieństwo. Wyrazem tej teologii jest tradycja deuteronomistyczna, zawarta w $\mathrm{Pwt}^{6}$.

5 Zagadnienia historyczno-krytyczne związane $\mathrm{z}$ autorstwem, miejscem i czasem powstania oraz Sitz im Leben Koh przedstawiają m.in.: M. Filipiak, Księga Koheleta. Wstęp - przektad z oryginatu - komentarz - ekskursy, Poznań-Warszawa 1980, s. 21-44; G. Ravasi, Kohelet. Najbardziej oryginalna i „skandaliczna” ksiegga Starego Testamentu, przeł. J. Skrzypnik, Kraków 2003, s. 13-51.

6 Na temat historii powstania i teologii deuteronomisty: D. Dziadosz, Teocentryczna historiografia starożytnego Izraela, czyli kim byt Deuteronomista i jego dzieto, „Collectanea Theologica” 2004, t. 74, nr 4, s. 5-25; T.C. Römer, The So-called Deuteronomistic History. A Sociological, Historical and Literary Introduction, London-New York 2009; A. de Pury, T.C. Römer, J.D. Macchi, Israel Constructs its History: Deuteronomistic Historiography in Recent Research, Sheffield 2000; R.D. Nelson, The Double Redaction of the Deuteronomistic History, Sheffield 1981; F.A.J. Nielsen, The Tragedy in History: Herodotus and Deuteronomistic History, Sheffield 1997. 
Opierając się na doświadczeniu, pokazuje jednostronność i błędność tradycyjnej doktryny odpłaty:

8,10 Ponadto widziałem, jak złoczyńców ze czcią składano w grobie, a ludzie przychodzili i odchodzili z miejsca świętego, i zapomniano w mieście o tym, co tamci czynili.

To również jest marność.

11 Ponieważ wyroku nad czynem złym nie wykonuje się zaraz, dlatego serce synów ludzkich bardzo jest skore do czynów złych; 12 zwłaszcza że grzesznik czyni źle stokrotnie, a jednak długo żyje.

Chociaż ja również $\mathrm{i}$ to poznałem, że szczęści się tym, którzy Boga się boją, dlatego że się Go boją. 13 Nie szczęści się zaś złoczyńcy, i podobny do cienia, nie przedłuża on swych dni, dlatego że nie ma w nim bojaźni wobec Boga.

14 Jest marność, która się dzieje na ziemi: są sprawiedliwi, którym się zdarza to, na co zasługują grzesznicy, a są grzesznicy, którym się zdarza to, na co zasługują sprawiedliwi.

Rzekłem: I to jest marność.

15 Sławiłem więc radość, bo nic dla człowieka lepszego pod słońcem, niż żeby jadł, pił i doznawał radości, $i$ by to go cieszyło przy jego trudzie za dni jego życia, które pod słońcem daje mu Bóg (Koh 8,10-15) ${ }^{7}$.

Zdarza się, że pomyślność towarzyszy sprawiedliwemu, ale nie brak sytuacji, kiedy to zły zażywa sławy i długich dni. Z drugiej strony, cierpienie jest udziałem zarówno sprawiedliwych, jak i niegodziwych. Kohelet powątpiewa więc w możliwość sformułowania jakiejś jednej reguły rozwiązującej dylemat teodycei. Jest to wyraz charakterystycznej dla Koheleta postawy krytycznej i sceptycznej. Głos Koheleta,

7 Wszystkie cytaty biblijne za BT wyd. 5: Pismo Święte Starego i Nowego Testamentu, Poznan 20005. Tekst oryginalny Biblii greckiej (LXX) za: Septuaginta, id est Vetus Testamentum graece iuxta LXX iterpretes, t. 1-2, red. A. Rahlfs, Stuttgart $1965^{2}$. 
podważający tradycyjną doktrynę odpłaty, nie jest odosobniony w Biblii hebrajskiej. Już w Księdze Hioba (=Hi) zakwestionowano takie podejście do problemu teodycei. Jednakże pomiędzy Koh a Hi istnieje delikatna różnica w postawie wobec sensu cierpienia. Stosunek Hioba doskonale ilustrują jego słowa wypowiedziane po zakończeniu mów Boga, w których ujrzał przekraczający rozum ludzki porządek wszechświata oraz istnienie mitycznych istot (Hi 38,1-41,26):

42,1 Hiob na to odpowiedział Panu, i rzekł:

2 „Wiem, że Ty wszystko możesz, co zamyślasz, potrafisz uczynić.

3 Kto przesłania zamiar nierozumnie?

O rzeczach wzniosłych mówiłem.

To zbyt cudowne. Ja nie rozumiem.

4 Posłuchaj, proszę. Pozwól mi mówić!

Chcę spytać. Racz odpowiedzieć!

5 Dotąd Cię znałem ze słyszenia, obecnie ujrzałem Cię wzrokiem, 6 stąd odwołuję, co powiedziałem, kajam się w prochu i w popiele" (Hi 42,1-6).

Hiob uznaje, że skoro nie jest w stanie ogarnąć rozumem Bożego dzieła stworzenia, to tym bardziej nie jest $\mathrm{w}$ stanie $\mathrm{w}$ pełni zrozumieć sensu cierpienia, którego doświadcza człowiek (Hi 42,1-6). Autor Hi ukazuje więc ludzką bezsilność w poszukiwaniu odpowiedzi na pytania dotyczące teodycei. Człowiekowi nie jest dany dostęp do Bożej mądrości, kierującej biegiem świata. Jedyna mądrość, jaką każdy może nabyć, to bojaźń Boża (Hi 28,28). Uświadomienie sobie niepoznawalności przyczyn niezasłużonego cierpienia jest możliwe jedynie poprzez doświadczenie, a nie drogą rozumowej spekulacji to ono otwiera Hiobowi oczy na jego niewiedzę (Hi 42,5). Ostatecznie Hiob uznaje absolutną władzę i transcendencję Boga, kierując się cnotą Bożej bojaźni. Ten religijny motyw posłuszeństwa podkreśla, że tylko w taki sposób można właściwie zareagować na doświadczenie niezasłużonego zła. Postawa Hioba jest zatem ostatecznie warunkowana religijnie i wiąże się z uznaniem ludzkich ograniczeń poznawczych oraz faktycznym podporządkowaniem się porządkowi nadprzyrodzonemu. Innymi słowy, Bożymi działaniami kieruje jakaś logika, co autor Hi określa mianem mądrości (por. Hi 28), ale jest ona poza zasięgiem ludzkiego rozumu. Jedynie doświadczenie, przeżycie, pozwala na dotarcie do granic ludzkiego poznania, dotknięcie 
granicy, poza którą już człowiek swoim intelektem nie sięga. Od tego momentu może zaczać się jedynie wiara, która akceptuje to co niepoznawalne i ufa, że jest w tym ukryta jakaś „wyższa” logika ${ }^{8}$.

Kohelet, podobnie jak Hiob, nie jest w stanie dostrzec sensu cierpienia, co podkreśla fragment Koh 8,10-15, jednak ten fakt nie prowadzi go uznania jakieś wyższej racji Bożego postępowania. Zestawiając ze sobą przykłady sprawiedliwego i nieprawego, którzy w równym stopniu moga zaznać w życiu szczęścia i nieszczęścia, sugeruje $\mathrm{w}$ istocie, że niepodobna nawet przeczuwać istnienia jakiegoś głębszego sensu czy też logiki w zastanych faktach. Innymi słowy, taka jest kolej rzeczy, taki jest bieg tego świata. Nie ma żadnych racjonalnych prawideł i reguł rządzących tu na ziemi. Chociaż w Koh pojawia się bliżej niesprecyzowana idea Bożego sądu nad prawym i złym (por. Koh 3,17), to jednak bardzo ciężko wskazać, kiedy taki sąd ma miejsce, czy w doczesności czy po śmierci, oraz jaka kieruje nim logika. Problem teodycei w Koh pokazuje, że ludzkim życie nie kieruje jakaś jasno rozpoznawalna reguła. Można powiedzieć, że świat jest niejako pozostawiony sam sobie, stąd zarówno zło, jak i pomyślność może dotknąć każdego. Zwróćmy uwagę na początek księgi, gdzie Kohelet daje syntetyczny obraz rozumienia rzeczywistości:

1,2 Marność nad marnościami, powiada Kohelet, marność nad marnościami - wszystko marność.

3 Cóż przyjdzie człowiekowi z całego trudu, jaki zadaje sobie pod słońcem?

4 Pokolenie przychodzi i pokolenie odchodzi, a ziemia trwa po wszystkie czasy.

5 Słońce wschodzi i zachodzi, i na miejsce swoje spieszy z powrotem, i znowu tam wschodzi.

$6 \mathrm{Ku}$ południowi ciągnąc i ku północy wracając, kolistą drogą wieje wiatr i znowu wraca na drogę swojego krążenia.

7 Wszystkie rzeki płyną do morza, a morze wcale nie wzbiera;

do miejsca, do którego rzeki płyną,

8 Szerzej na temat problemu teodycei w Hi: A. Tronina, Ksiega Hioba. Wstępprzektad z oryginatu - komentarz, Częstochowa 2013, s. 577-578; S. Carmy, D. Schatz, Biblia jako źódto refleksji filozoficznej, w: Historia filozofii żydowskiej, red. D.H. Frank, O. Leaman, Kraków 2009, s. 36-39. 
zdążają one bezustannie.

8 Mówienie jest wysiłkiem:

nie zdoła człowiek wyrazić [wszystkiego] słowami.

Nie nasyci się oko patrzeniem

ani ucho napełni słuchaniem.

9 To, co było, jest tym, co będzie,

a to, co się stało, jest tym, co znowu się stanie:

więc nic zgoła nowego nie ma pod słońcem.

10 Jeśli jest coś, o czym by się rzekło:

„Patrz, to coś nowego" -

to już to było w czasach,

które były przed nami.

11 Nie ma pamięci o tych, co dawniej żyli,

ani też o tych, co będą kiedyś żyli,

nie będzie wspomnienia u tych, co będą potem (Koh 1,2-11).

Kluczowym terminem, który charakteryzuje cały porządek doczesny, jego elementy pozytywne jak i negatywne, jest rzeczownik chervel, który w polskich przekładach oddawany jest jako "marnośc”. W języku hebrajskim oznacza on przede wszystkim „mgłę”, „parę”, „tchnienie”, czyli coś ulotnego, nieuchwytnego i całkowicie nietrwałego. Taki jest też porządek rzeczywistości, nietrwały i zmienny, a jednocześnie w świecie nie możemy i nie powinniśmy oczekiwać jakichś radykalnych przełomów. Jak twierdzą niektórzy komentatorzy, jest to krytyka pewnych prorockich i apokaliptycznych scenariuszy eschatologicznych, które oczekiwały radykalnego przeobrażenia obecnej, złej i znieprawionej rzeczywistości, wyglądając różnie przedstawianego czasu mesjańskiego ${ }^{9}$. Jedynym elementem, któremu można przypisać cechę stałości, jest właśnie owa nietrwałość i zmienność rzeczy.

To doświadczenie nie skutkuje jednak u Koheleta jaką́s postawą wyraźnej religijnej ufności i wiary w nadprzyrodzony boski plan, który tylko dla człowieka pozostaje niezrozumiały. Kohelet jest w tym przypadku dużo bardziej sceptyczny. Nie formułuje on żadnych jednoznacznych i precyzyjnych sądów na temat relacji pomiędzy istnieniem zła a osobą Boga. Nie eksponuje też tak mocno religijnej cnoty posłuszeństwa i bojaźni Bożej. Odwołuje się raczej do postawy, z ducha epikurejskiej, rozumnego korzystania z dóbr, które człowiek otrzymał od Boga (Koh 8,15).

9 Na temat eschatologicznych poglądów Koh: J. Lemański, Eschatologia, w: Teologia Starego Testamentu. Ksiegi Mądrościowe, t. 1, red. M. Rosik, Wrocław 2011, s. 229-237. 
Co warunkuje taki stosunek Koheleta do problemu teodycei? Dlaczego pozwala sobie na formułowanie wątpliwości i sądów, które stawiają go na granicy swoistej „ortodoksji” wczesnego judaizmu? Wydaje się, że Kohelet zauważa niewystarczalność lub też pewną nieadekwatność tradycyjnych wartości, norm czy też idei religijnych i mądrościowych, proponowanych przez religię przodków. Podobnie jak Hiob, Kohelet ma za punkt wyjścia obserwację i doświadczenie rzeczywistości, które wymykają się schematycznym klasyfikacjom i uniemożliwiają formułowanie jednoznacznych reguł. Wydaje się, że taka postawa mogła narodzić się tylko w kontekście konfrontacji z alternatywnymi światopoglądami, które niejako zrelatywizowały pozycję judaizmu. W okresie perskim (VI - pierwsza połowa IV w. przed Chr.) judaizm przeżywał okres odbudowy swojej tożsamości, po kryzysie związanym $z$ upadkiem Judy i zniszczeniem świątyni w Jerozolimie (586 r. przed Chr.). Wpływy kultury i religii perskiej na judaizm nie były zbyt intensywne. Natomiast od drugiej połowy IV w. przed Chr., a zwłaszcza w III w. przed Chr., na terenie Ziemi Izraela, zajmowanej przez Ptolemeuszy, upowszechnia się kultura helleńska. Jest to okres wpływu, który nie ma charakteru jakiejś ekspansji ideologicznej, jak to będzie miało miejsce w II w. przed Chr., za czasów Antiocha IV Epifanesa, niemniej jednak dotyka wielu obszarów żydowskiej tożsamości. Chodzi zwłaszcza o kręgi wykształconych, którzy mieli bardziej otwarty i szeroki dostęp do nowych idei. A do takiej klasy społecznej należał najprawdopodobniej Kohelet. Innymi słowy, spotkanie $z$ hellenizmem i jego ludowymi filozofiami zrelatywizowały w oczach wielu mędrców żydowskich tradycyjne poglądy na świat. Kohelet, wnikliwy obserwator rzeczywistości i wrażliwy na różnego rodzaju doświadczenia, najprawdopodobniej uległ po części wpływom idei zbliżonych do sceptycyzmu i epikureizmu10. Oczywiście nie porzucił judaizmu i swojej tożsamości etniczno-religijnej, o czym świadczy przede wszystkim hebrajski język księgi, jednak nowe idee pozwoliły mu na krytyczny stosunek do wielu elementów mądrościowej tradycji Izraela. Hellenizm stworzył w kręgach ludzi wykształconych i wysoko postawionych w judejskiej społeczności przestrzeń do dyskusji i wątpliwości. Być może dlatego Kohelet nie

10 Na związki Koh z epikureizmem i sceptycyzmem w wersji ludowej filozofii:

G. Ravasi, Kohelet, dz. cyt., s. 324-330. 
bał się formułować swoich przemyśleń i zadawać pytań, które stawiały go na granicy tradycyjnego judaizmu. Prawdopodobnie w III w. przed Chr. w Jerozolimie istniało grono mędrców, którzy nie ulegając całkowitej hellenizacji, wykorzystywali wiele idei i myśli greckiej filozofii ludowej, aby na nowo spojrzeć na świat oraz swoją ojczystą religię. Skoro hellenizm nie napierał jeszcze agresywnie na judaizm, jak w II w. przed Chr., to również reakcja na takie postawy nie była jeszcze zbyt mocna. Po prostu bardziej konserwatywne kręgi religijne oraz zwykła ludność Judei ignorowała intelektualne „wybryki” nielicznych mędrców pokroju Koheleta ${ }^{11}$.

\section{Księga mądrości a relatywizacja tradycyjnych wartości i norm}

Księga Mądrości (=Mdr), podobnie jak Koh, jest utworem pseudoepigraficznym, którego autor przedstawia się jako król Salomon. Mamy jednak do czynienia $\mathrm{z}$ dziełem napisanym pierwotnie $\mathrm{w}$ języku greckim, stąd zaliczanym do tzw. ksiąg deuterokanonicznych, a skomponowanym prawdopodobnie na terenie diaspory egipskiej, być może nawet w samej Aleksandrii. Badacze utrzymują, że druga połowa I w. przed Chr. lub pierwsza połowa I w. po Chr. to najbardziej możliwe daty powstania Mdr. $Z$ treści dzieła można wywnioskować, że autor był zhellenizowanym Żydem, zaznajomionym z popularnymi ludowymi systemami filozoficznymi hellenizmu, a jednocześnie pozostawał wierny religii swojego pochodzenia, tj. judaizmowi. Przedstawiając swoje poglądy na temat Boga, mądrości czy też historii wyjścia Izraela z Egiptu, posługuje się bardzo często terminologią, która czerpie wiele ze świata ideowego popularnej w basenie Morza Śródziemnego kultury greckiej. Chociażby opisując mądrość, używa on wielu terminów o filozoficznej proweniencji (por. Mdr 7,22-8,1) ${ }^{12}$. Podobnie, na poziomie antropologii pojawiają się rzeczowniki związane $\mathrm{z}$ dualizmem psychofizycznym (por. np. Mdr 1,4). Jednak wykorzystanie różnych środków literackich i motywów hellenistycznych pełni określoną funkcję $\mathrm{w}$ retorycznej strategii autora. W gruncie rzeczy celem autora Mdr jest

11 Zob. również: M. Hengel, Judaizm and Hellenism, dz. cyt., s. 115-128.

12 Zob. szczegółowe omówienie koncepcji mądrości i jej atrybutów w Mdr: B. Poniży, Obraz (Oblicze) Boga, w: Teologia Starego Testamentu, dz. cyt., s. 85-91. 
obrona tradycyjnych wartości judaizmu, chociaż wyrażonych za pomocą języka sięgającego do hellenizmu. Przyjrzyjmy się zatem stosunkowi Mdr do problemu teodycei ${ }^{13}$.

Problematyka teodycealna w rozważaniach Mdr nie ma charakteru abstrakcyjnego. Nie jest analizowana jako zagadnienie samo w sobie. Uwaga autora ogniskuje się wokół przypadku sprawiedliwego, wiernego Torze młodzieńca, który jednak doświadcza przedwczesnej śmierci. Sytuacja tego człowieka jest przedmiotem oceny bezbożnych, którzy początkowo zupełnie nie rozumieją zasadniczej różnicy pomiędzy jego a ich położeniem. Tak Mdr charakteryzuje owych bezbożnych:

1,16 Bezbożni zaś ściągają ją na siebie słowem i czynem, usychają, uważając ją za przyjaciółkę, i zawierają $\mathrm{z}$ nią przymierze, zasługują bowiem na to, aby być jej działem.

2,1 Mylnie rozumując, mówili sobie:

„Nasze życie jest krótkie i smutne.

Nie ma lekarstwa na śmierć człowieczą, nie znamy nikogo, kto by wrócił z Otchłani.

2 Urodziliśmy się niespodzianie

i potem będziemy, jakby nas nigdy nie było.

Dech w nozdrzach naszych jak dym, myśl jak iskierka $z$ uderzeń serca naszego:

3 gdy ona zgaśnie, ciało obróci się w popiól, a duch się rozpłynie jak niestałe powietrze.

4 Imię nasze pójdzie z czasem w niepamięć i nikt nie wspomni naszych poczynań.

Przeminie życie nasze jakby ślad obłoku

i rozwieje się jak mgła,

ścigana promieniami słońca

i żarem jego przybita.

5 Czas nasz jak cień przemija, śmierć nasza nie zna odwrotu:

pieczęć przyłożono, i nikt nie powraca.

6 Nuże więc! Korzystajmy z tego, co dobre, skwapliwie używajmy świata w młodości!

13 Zagadnienia historyczno-krytyczne związane z problemem autorstwa, czasu i miejsca powstania oraz Sitz im Leben Mdr: K. Romaniuk, Ksiegga Mqdrości. Wstep - przektad z oryginatu-komentarz-ekskursy, Poznań-Warszawa 1969, s. 15-50; B. Poniży, Obraz (Oblicze) Boga, w: Teologia Starego Testamentu, dz. cyt., s. 59-60; tenże, Ksiegga Mądrości. Wstęp - przektad z oryginatu - komentarz, Częstochowa 2012. 
7 Upijmy się winem wybornym i wonnościami i niech nam nie ujdą wiosenne kwiaty:

8 uwijmy sobie wieniec $\mathrm{z}$ róż, zanim zwiędną.

9 Nikogo z nas braknąć nie może w swawoli, wszędzie zostawmy ślady uciechy:

bo to nasz dział, nasze dziedzictwo!" (Mdr 1,16-2,9)

Kto kryje się za tą charakterystyką? Chodzi prawdopodobnie o silnie zhellenizowanych Żydów, reprezentujących wyższe warstwy diaspory, którzy ulegli daleko idącej asymilacji z pogańską społecznością swojego środowiska zamieszkania. W ich stosunku do życia zauważamy silne wpływy ludowej formy epikureizmu, zabarwionej jednak również pesymizmem i sceptycyzmem. Innymi słowy, porzucenie judaizmu doprowadziło ich do przyjęcia radykalnie odmiennego sposobu życia od tego, który proponuje religia Mojżeszowa ${ }^{14}$. Postawa ta była motywowana być może chęcią całkowitego odcięcia się od żydowskiej diaspory i pokazania pogańskiemu otoczeniu, że proces asymilacji jest zupełny. Zachowania tego typu były bardzo często motywowane antysemityzmem, obecnym silnie w kulturze grecko-rzymskiej. Wyznawcy judaizmu jawili się poganom jako ludzie antyspołeczni, odizolowani od cywilizacji i kultury basenu Morza Śródziemnego ${ }^{15}$. Zatem osoba, która pragnęła dołączyć w pełni do hellenistycznej ekumeny, powinna całkowicie odciąć się od judaizmu. Bardzo częstym zjawiskiem w tym procesie było chociażby przeprowadzanie zabiegu mającego na celu ukrycie obrzezania. $\mathrm{Za}-$ tem dla wielu przedstawicieli egipskiej diaspory judaizm stawał się balastem, który należy porzucić, bowiem jego wartości i normy nijak nie przystają do hellenistycznego świata. Taka postawa jest bardzo negatywnie oceniania przez autora Mdr, na co wskazuje wyraźnie charakterystyka bezbożnych w Mdr 1,16-2,9.

Największym zagrożeniem dla nowej tożsamości owych bezbożnych jest Żyd pozostający wierny religii przodków, który jednocześnie wyraźnie krytykuje swoich zasymilowanych i zhellenizowanych pobratymców:

Szczegółowa analiza mowy owych bezbożnych: K. Siwek, Honor sprawiedliwego, dz. cyt., s. 298-383.

15 Antysemityzm antyczny omawia m.in.: L. Poliakov, Historia antysemityzmu. Epoka wiary, t. 1, przeł. A. Rasińska-Bóbr, O. Hedemann, Kraków 2008, s. 5-17. 
2,12 Zróbmy zasadzkę na sprawiedliwego, bo nam niewygodny:

sprzeciwia się naszym sprawom,

zarzuca nam łamanie prawa,

wypomina nam błędy naszych obyczajów.

13 Chełpi się, że zna Boga,

zwie siebie dzieckiem Pańskim.

14 Jest potępieniem naszych zamysłów, sam widok jego jest dla nas przykry,

15 bo życie jego niepodobne do innych

i drogi jego odmienne.

16 Uznał nas za coś fałszywego

i stroni od dróg naszych jak od nieczystości.

Kres sprawiedliwych ogłasza za szczęśliwy

i chełpi się Bogiem jako ojcem.

17 Zobaczmy, czy prawdziwe są jego słowa, wybadajmy, co będzie przy jego zejściu.

18 Bo jeśli sprawiedliwy jest synem Bożym,

Bóg ujmie się za nim

i wyrwie go z ręki przeciwników.

19 Dotknijmy go obelgą i katuszą,

by poznać jego łagodność

i doświadczyć jego cierpliwości.

20 Zasądźmy go na śmierć haniebną,

bo - jak mówił - będzie ocalony (Mdr 2,12-20).

Wersety te pokazują na istnienie napięcia i wyraźnej niechęci pomiędzy tymi członkami diaspory egipskiej, którzy wciąż praktykowali judaizm i jednocześnie bardzo mocno krytykowali różne formy odstępstwa, a tymi, którzy szukali różnych dróg kompromisu $\mathrm{z}$ hellenizmem, włączając w to proces całkowitej asymilacji. I właśnie w tym kontekście społeczno-religijnym należy umieścić problem teodycei w Mdr.W oczach bezbożnych śmierć sprawiedliwego, czyli wiernego Torze wyznawcę judaizmu, jest klęską, czymś całkowicie niezrozumiałym. W myśl ich pesymistycznego i epikurejskiego światopoglądu mamy do czynienia ze zmarnowanym życiem. Tora wraz z jej wieloma przykazaniami i przepisami krępuje bowiem wolność człowieka, nie pozwalając korzystać ze wszystkich uroków życia. Ponadto, bezbożni pozbawieni są też wiary w etyczną nagrodę i karę po śmierci, stąd ich tak krytyczna ocena przedwcześnie zmarłego sprawiedliwego. $\mathrm{Z}$ kolei autor Mdr podkreśla, że osąd bezbożnych jest zupełnie chybiony, nie uwzględnia bowiem wierności Boga wobec swojego ludu. Zwróćmy uwagę na dwa kluczowe fragmenty Mdr, w których przedstawiono eschatologiczny los zmarłego sprawiedliwego: 
2,21 Tak pomyśleli - i pobłądzili,

bo własna złość ich zaślepiła.

22 Nie pojęli tajemnic Bożych, nie spodziewali się nagrody za prawość

i nie docenili odpłaty dusz czystych.

23 Bo dla nieśmiertelności Bóg stworzył człowieka uczynił go obrazem swej własnej wieczności.

24 A śmierć weszła na świat przez zawiść diabła

i doświadczają jej ci, którzy do niego należą.

3,1 A dusze sprawiedliwych są w ręku Boga

i nie dosięgnie ich męka.

2 Zdało się oczom głupich, że pomarli,

zejście ich poczytano za nieszczęście

3 i odejście od nas za unicestwienie,

a oni trwają w pokoju.

4 Choć nawet w ludzkim rozumieniu doznali kaźni, nadzieja ich pełna jest nieśmiertelności.

5 Po nieznacznym skarceniu dostąpią dóbr wielkich,

Bóg ich bowiem doświadczył

i znalazł ich godnymi siebie.

6 Doświadczył ich jak złoto w tyglu

i przyjął ich jak całopalną ofiarę.

7 W dzień nawiedzenia swego zajaśnieją

i rozbiegną się jak iskry po ściernisku.

8 Będą sądzić ludy, zapanują nad narodami,

a Pan królować będzie nad nimi na wieki.

$9 \mathrm{Ci}$, którzy Mu zaufali, zrozumieją prawdę, wierni w miłości będą przy Nim trwali:

łaska bowiem i miłosierdzie dla Jego wybranych (Mdr 2,21-3,9).

4,7 A sprawiedliwy, choćby umarł przedwcześnie, znajdzie odpoczynek.

8 Starość jest czcigodna nie przez długowieczność

i liczbą lat się jej nie mierzy:

9 sędziwością u ludzi jest mądrość,

a miarą starości - życie nieskalane.

10 Ponieważ spodobał się Bogu, znalazł Jego miłość, i żyjąc wśród grzeszników, został przeniesiony.

11 Zabrany został, by złość nie odmieniła jego myśli

albo ułuda nie uwiodła duszy:

12 bo urok marności przesłania dobro,

a burza namiętności mąci prawy umysł.

13 Wcześnie osiągnąwszy doskonałość, przeżył czasów wiele.

14 Dusza jego podobała się Bogu,

dlatego pospiesznie wyszedł spośród nieprawości.

A ludzie patrzyli i nie pojmowali,

ani sobie tego nie wzięli do serca, 
15 że łaska i miłosierdzie nad Jego wybranymi

i nad świętymi Jego opatrzność.

16 Sprawiedliwy umarły potępia żyjących bezbożnych, i dopełniona wcześnie młodość - leciwą starość nieprawego.

17 Zobaczą bowiem kres roztropnego, a nie pojmą, co o nim Pan postanowił

i w jakim celu zachował go bezpiecznym.

18 Patrzą i żywią pogardę, ale Pan ich wyśmieje (Mdr 4,7-18).

Perykopy Mdr 2,21-3,9 oraz 4,7-18 są niezwykle ciekawe pod względem obecności idei i motywów nawiązujących do świata wartości judaizmu i hellenizmu. Zwróćmy uwagę chociażby na Mdr 2,23, gdzie autor wyraża swoje przekonanie, że celem ludzkiego życia jest nieśmiertelność, opierająca się na jego podobieństwie do Boga. $Z$ jednej strony, mamy w tym wersecie rzeczownik aftharsia, który ma wyraźnie filozoficzne konotacje i oznacza „nieśmiertelność”, „niezniszczalność”, „nieskalaność”. Z drugiej, idea człowieka jako eikon („obrazu”) Boga intertekstualnie nawiązuje do Rdz 1,26-26 LXX. W Mdr 3,6, kreśląc obraz cierpienia sprawiedliwego i jego śmierci, autor posługuje się metaforą ofiary całopalnej (gr. bolokarpoma), znanej z żydowskiego kultu ofiarniczego. Natomiast w Mdr 3,1; 4,11.14 pojawia się rzeczownik psyche („dusza”), który w antropologii hellenistycznej ma szeroki zakres semantyczny, ale zasadniczo odnosi się do racjonalnego i duchowego/ subtelnego elementu w człowieku, często będąc przeciwstawianym terminowi soma („ciało”). Komentatorzy zauważają, że autor Mdr nie przyjmuje całkowicie dualizmu psychofizycznego, charakterystycznego dla niektórych nurtów w filozofii greckiej, np. dla platonizmu, a bardzo często rozumie psyche na sposób semicki ${ }^{16}$. Rzeczownik psyche odpowiada bowiem hebrajskiemu nefesz, który oznacza przede wszystkim „życie”, „istotę”, „osobę”. Wydaje się, że ta ambiwalencja w posługiwaniu się greckim terminem psyche jest zamierzona przez autora, który szuka adekwatnego słownego wyrazu dla przekazania idei o eschatologicznym darze wiecznego życia dla sprawiedliwych wyznawców judaizmu, którzy pozostali wierni Bogu ojców ${ }^{17}$.

16 Na temat eschatologicznych poglądów autora Mdr: J. Lemański, Eschatologia, w: Teologia Starego Testamentu, dz. cyt., s. 242-251.

17 Zob. również na ten temat: T. Zaklukiewicz, Nieśmiertelność sprawiedliwych. Idea nieśmiertelności w Księdze Mądrości, Wrocław 2017. 
W Mdr problem teodycei jest zatem rozważany na bazie konkretnego przypadku sprawiedliwego Żyda, który za swoją wierność Torze przedwcześnie umiera. Nie jest to zmarnowane życie, jak utrzymują bezbożni, zhellenizowani Żydzi. W oczach autora Mdr Bóg obdarza takie osoby wiecznym życiem, zabierając je z tego zepsutego świata i w ten sposób chroniąc przez skalaniem się i grzechem. Innymi słowy, ocena ludzkiego życia, ograniczona jedynie do poziomu doczesności i mierzona jedynie sumą przyjemności oraz krzywd, nie pozwala na zrozumienie sensu cierpienia osób wiernych judaizmowi. Dopiero spojrzenie z perspektywy religijnej, uwzględniającej Boga i jego mądrość, pozwala na właściwe odczytanie sensu życia i śmierci sprawiedliwego. Aby wyrazić to swoje głębokie przekonanie i dać jednocześnie nadzieję swoim pobratymcom i członkom jednej wspólnoty religijnej, autor Mdr posługuje się ideami i wartościami judaizmu, jak i hellenizmu. Dla członków diaspory egipskiej język obu tych światopoglądów był znany i zrozumiały, stąd taka decyzja i strategia retoryczna pisarza biblijnego. Wydaje się, że w ujęciu Mdr kultura hellenistyczna nie jest oceniana ani całkowicie pozytywnie, ani negatywnie. Stanowi raczej kulturowo-społeczne tło, w którym autor funkcjonuje. Dostrzega on, że pewne formy kultury hellenistycznej oraz popularnej filozofii greckiej, jak epikureizm czy sceptycyzm, doprowadziły wielu jego współrodaków do całkowitej asymilacji ze światem pogańskim, co wiązało się z porzuceniem judaizmu. Jednocześnie, posługując się językiem i ideami związanymi z kulturą grecką stara się pokazać, że judaizm może być praktykowany i zrozumiały w ramach światopoglądu hellenistycznego.

\section{Zakończenie, czyli próba aktualizacji}

Autorzy Koh i Mdr w bardzo odmienny sposób reagują na pojawienie się w Ziemi Izraela kultury hellenistycznej. Dla Koheleta zetknięcie się z popularną filozofią grecką stanowi impuls dla krytycznej i sceptycznej oceny wielu tradycyjnych idei, obecnych w literaturze madrościowej judaizmu. W księdze tej można dostrzec ślady koncepcji zbliżonych do epikureizmu i sceptycyzmu, które prowadzą autora na granicę judaistycznej prawowierności. Wydaje się, że taka wolność i swoboda myśli była możliwa właśnie dzięki pojawieniu się hellenizmu w środowiskach elity intelektualnej Jeruzalem. W przypadku Mdr mamy do czynienia $z$ tekstem, który próbuje wykorzystać elementy 
hellenizmu przeciwko tym spośród jego rodaków, którzy ulegli zbytniej hellenizacji. Inaczej mówiąc, autor Mdr pokazuje, że wiara judaistyczna może być wyrażona za pomocą pojęć i wartości charakterystycznych dla kultury greckiej. Żyd może pozostać wierny religii ojców, a jednocześnie partycypować w helleńskiej polis. Uleganie skrajnej formie asymilacji, połączonej z porzucaniem judaizmu, nie jest zatem jedynym modelem przyswajania kultury hellenistycznej przez Żydów.

Spróbujmy dokonać „aktualizacji” wspomnianych wyżej poglądów myślicieli biblijnych, starając umieścić ich postawy i idee w postnowoczesnej sytuacji relatywizacji oraz chaosu wartości i norm, doświadczanych przez chrześcijan XXI wieku. Postawa Koheleta może być odniesiona do tych nurtów ponowoczesnego chrześcijaństwa zachodniego, które w kontakcie ze współczesnymi wartościami i koncepcjami, ulegają swoistej relatywizacji i transformacji. W wielu przypadkach zachodnie chrześcijaństwo dokonuje ponownej, krytycznej refleksji nad swoją doktryną i praktykami. Odwołując się do nowych koncepcji filozoficznych czy socjologicznych, takich jak feminizm, gender, ekologizm, stara się zredefiniować swoją tożsamość, pozostając jednak nominalnie wierne podstawowej idei chrześcijaństwa, miłości Boga i bliźniego. W oczach bardziej tradycyjnych wiernych taki kierunek zmian jest postrzegany jako zbyt daleko idąca liberalizacja, przekraczająca granice kościelnej ortodoksji. Z kolei postawa autora Mdr doskonale pasuje do tych nurtów współczesnego chrześcijaństwa, które szukają kompromisu i równowagi pomiędzy tradycją a nowoczesnością. Trwa $\mathrm{w}$ nich poszukiwanie takiego sposobu komunikacji i życia, który byłby w stanie wyrazić „stare” prawdy i praktyki, za pomocą kategorii zrozumiałych dla człowieka ponowoczesnego. Oczywiście proces ten rodzi wiele trudności i napięć, niemniej wydaje się, że współczesny katolicyzm, ukształtowany po Soborze Watykańskim II, stara się kroczyć właśnie tą drogą, której ideowym prekursorem był autor Mdr. Czy droga ta jest słuszna, pokaże czas.

\section{Bibliografia}

Bauman Z., Etyka ponowwoczesna, przeł. J. Bauman, J. Tokarska-Bakir, Wydawnictwo Aletheia, Warszawa 2012.

Carmy S., Schatz D., Biblia jako zródto refleksji filozoficznej, w: Historia flozofii żydowskiej, red. D.H. Frank, O. Leaman, Wydawnictwo WAM, Kraków 2009, s. 25-50. 
Dziadosz D., Teocentryczna historiografia starożytnego Izraela, czyli kim byt Deuteronomista i jego dzieto, „Collectanea Theologica” 2004, t. 74, nr 4, s. 5-25.

Filipiak M., Ksiegga Koheleta. Wstep - przektad z oryginatu - komentarz-ekskursy, Pallottinum, Poznań-Warszawa 1980.

Gadamer H.-G., Prawda i metoda. Zarys hermeneutyki filozoficznej, przet. B. Baran, Wydawnictwo Naukowe PWN, Warszawa 2007.

Hengel M., Judaizm and Hellenism, trans. J. Bowden, t. 1, Fortress Press, Philadelphia 1974.

Johnson P., Historia Żydóww, przeł. M. Godyń, M. Wójcik, A. Nelicki, Wydawnictwo Platan, Kraków 1993.

Lemański J., Eschatologia, w: Teologia Starego Testamentu. Księgi Mądrościowe, t. 1, red. M. Rosik, Wydawnictwo TUM, Wrocław 2011, s. 213-252.

Mélèze-Modrzejewski J., Żydzi nad Nilem. Od Ramzesa II do Hadriana, przeł. J. Olkiewicz, The Enigma Press, Kraków 2000.

Nelson R.D., The Double Redaction of the Deuteronomistic History, "Journal for the Study of the Old Testament", Supplement Series 18, Sheffield Academic Press, Sheffield 1981.

Nielsen F.A.J., The Tragedy in History: Herodotus and Deuteronomistic History, Sheffield Academic Press, Sheffield 1997.

Pismo Święte Starego i Nowego Testamentu, Pallottinum, Poznań $2000^{5}$.

Poliakov L., Historia antysemityzmu. Epoka wiary, t. 1, przeł. A. Rasińska-Bóbr, O. Hedemann, Universitas, Kraków 2008.

Poniży B., Ksiega Mąrości. Wstęp-przektad z oryginatu - komentarz, Edycja św. Pawła, Częstochowa 2012.

Poniży B., Obraz (Oblicze) Boga, w: Teologia Starego Testamentu. Ksiegri Mqdrościowe, red. M. Rosik, t. 1, Wydawnictwo TUM, Wrocław 2011, s. 7-2.

Pury A. de, Römer T.C., Macchi J.-D., Israel Constructs its History: Deuteronomistic Historiography in Recent Research, ,Journal for the Study of the Old Testament", Supplement Series 306, Sheffield Academic Press, Sheffield 2000.

Ravasi G., Kohelet. Najbardziej oryginalna i "skandaliczna" ksiega Starego Testamentu, przeł.J. Skrzypnik, Wydawnictwo Salwator, Kraków 2003.

Romaniuk K., Ksiega Madrości. Wstęp - przektad z oryginatu - komentarz ekskursy, Pallottinum, Poznań-Warszawa 1969.

Römer T.C., The So-called Deuteronomistic History: A Sociological, Historical and Literary Introduction, T\&T Clark, London-New York 2009.

Septuaginta, id est Vetus Testamentum graece iuxta LXX interpretes, t. 1-2, red. A. Rahlfs, Deutsche Bibelgesellschaft, Stuttgart $1965^{2}$.

Siwek K., Honor sprawiedliwego $i$ wstyd bezbożnego w antropologicznokulturowej interpretacji Mdr 1-5, Bractwo Słowa Bożego, Apostolicum Wydawnictwo Księży Pallotynów Prowincji Chrystusa Króla, Warszawa-Ząbki 2016. 
Tronina A., Ksiega Hioba. Wstep - przektad z oryginatu - komentarz, Edycja św. Pawła, Częstochowa 2013.

VanderKam J.C., Wprowadzenie do wczesnego judaizmu, przeł. P. Krupczyński, Wydawnictwo Cyklady, Warszawa 2006.

Warzecha J., Historia dawnego Izraela, Wydawnictwo Uniwersytetu Kardynała Stefana Wyszyńskiego, Warszawa 2005.

Zaklukiewicz T., Nieśmiertelność sprawiedliwych. Idea nieśmiertelności w Księdze Mądrości, Tum Wydawnictwo i Drukarnia Wrocławskiej Księgarni Archidiecezjalnej, Wrocław 2017.

\section{ADRES DO KORESPONDENCJI:}

Dr Piotr Goniszewski

Uniwersytet Szczeciński

Wydział Teologiczny

e-mail: piotr.goniszewski@usz.edu.pl 